\title{
3
}

\section{Manufacturing Coherence: How American Textbooks Incorporate Diverse Perspectives on the Origins of the Cold War}

\author{
Eva Fischer
}

\section{Introduction}

In 2010, the Texan State Board of Education, conservative by majority, voted in favour of changing the social studies curriculum standards. As well as mandating changes that would downplay numerous socio-political issues, board members demanded a more positive representation of US-style capitalism as a 'free enterprise system' and a stronger emphasis on the Soviet Union's aggressiveness during the Cold War. They viewed their actions as a fight 'for ... our nation's future' (McKinley 2010; NBC News 2010). ${ }^{1}$

Interpretations of the Cold War are interwoven with political and cultural values, and attached to notions of national identity. While this is true of many countries and societies (see Lowe and Joel 2013) it is the US where the concepts of 'freedom', 'progress' and 'exceptionalism', in the sense of superiority, have fed most strongly into a national master narrative (Foner 1999; Barton and Levstik 2009, 166-182; Pease 2007;

\section{E. Fischer $(\bowtie)$}

Independent Researcher, Oldenburg, Germany 
Paul 2014). During the Cold War, the US represented itself as the leader of the free world and defender against an evil, backward Soviet Union (Pease 2007). Revisionist and post-revisionist interpretations of the Cold War have challenged this master narrative, yet alternative views have not provided any widely accepted frameworks for redefining American history and identity (ibid., 112).

The academic debates around the Cold War pose a special challenge to US history textbooks. A medium of particular socio-political concern (Höhne 2002; Klerides 2010), they are expected both to provide accurate information and to construct coherent, identity-providing national narratives (Schissler 2009, 203-226) that satisfy a diverse audience of school boards, schools, activists, and lobby groups. This chapter explores representations of the contested era of the Cold War in major contemporary US history textbooks published between 2007 and 2012. I will focus on depictions of the origins of the conflict, an area of particular controversy. I restrict my investigation to textbooks for American history, which cover the Cold War in more detail than those on world history.

My first consideration was the extent to which contemporary textbooks have adopted alternative accounts. My first finding was that the representation of the origins of the Cold War in history textbooks by the three major US publishers Pearson, McGraw-Hill, and Holt McDougal/Houghton Mifflin Harcourt (American Textbook Council 2016) is anything but uniform. There are textbooks such as Glencoe/McGraw-Hill's The American Journey (Appleby, Brinkley and McPherson 2007) for middle schools, which represents a purely traditionalist narrative. At the other end of the spectrum we find, for example, Pearson's text-heavy, 'advanced'2 high-school textbook The American People (Nash and Jeffrey 2009), which explicitly locates US history within an international context, provides extensive discussion of both the Soviet and the US stances in the Cold War, and also focuses on the Third World. A large number of textbooks, however, seem to have adopted a middle ground between traditionalist and non-traditionalist interpretations, for example Glencoe/McGraw Hill's The American Vision (Appleby et al. 2007), Pearson's America: Past and Present (Divine et al. 2007), as well as Holt McDougal/Houghton Mifflin Harcourt's United States History (2012) and The Americans (Danzer et al. 2012).

Given the dominance of this middle course, I will focus on two highschool textbooks that combine traditionalist and non-traditionalist views: 
Glencoe/McGraw Hill's The American Vision (Appleby et al. 2007) and Holt McDougal/Houghton Mifflin Harcourt's The Americans (Danzer et al. 2012). This specific focus allows me to encompass macro-textual strategies, broad argumentative patterns and linguistic realisations at micro-level (Martin and Wodak 2003, 1). By looking, for example, at sentence construction and word choice in context, I undertake what John Issitt has described as breaking down the elements of textbooks in order to refute the widely-held assumption of their bland neutrality and reveal how they 'share in the production of a hegemony of ideas' (Issitt 2004, 689). My analysis will also attend to methods of presentation, to the use of primary sources as well as exercises and graphs, and to what is not said (Issitt 690). Analysing how the textbooks incorporate various interpretative patterns and create ostensible common-sense assumptions (Baier, Christophe and Zehr 2014), I wish to explore the degree of public acceptance of alternative accounts of the Cold War as manifested in the textbooks as reflections of what society has deemed desirable for students to learn.

Joseph Moreau has demonstrated that US textbooks have integrated alternative narrative elements either by making them fit traditional narrative structures, as was the case when African-American history was introduced through the themes of 'freedom' and 'progress', or by physically separating them from the main text, as exemplified in sidebars containing Southern interpretations of the Civil War (Moreau 2003). I argue that these strategies are also central to the representation of divergent perspectives on the Cold War and its major actors. In The American Vision, revisionist and post-revisionist elements are incorporated, in a watered-down version, into the master narrative. In The Americans, the principle of physical distinction of alternative narratives makes it possible to relegate revisionist interpretations to the background. At one point, however, as we will discuss, revisionist elements creep into the core narrative.

My findings give rise to multi-layered implications. The co-existence of multiple interpretative patterns supports the assumption that modern textbooks mirror debates rather than telling coherent stories (Lachmann and Mitchell 2014). At the same time, the textbooks reveal a reluctance to lend revisionist accounts of the Cold War the same credibility as traditionalist and post-revisionist interpretations and to renounce an unbrokenly positive national self-image. This indicates that non-traditionalist views have become acceptable and integrated only to a point where they 
do not challenge the national master narrative too explicitly, which is in line with what Michael Apple (1990, 25-26) describes as 'attempts at rebuilding hegemonic control'. As perspectives of less powerful groups are incorporated under the umbrella of hegemonic discourse, the dominance of that discourse in and through textbooks is partly maintained [...] through compromise and the process of "mentioning"', which leaves the major ideological framework largely untouched. ${ }^{3}$ The fact that revisionist elements do enter the core narrative at certain points, however, indicates that 'progressive echoes' (ibid., 26) in textbooks are becoming louder.

\section{Traditionalist, Revisionist and Post-Revisionist Interpretations of Selected Cold War Events}

According to traditionalist Western interpretations of the origins of the Cold War, a backward and aggressive Soviet Union was solely responsible for the outbreak of the conflict, whereas the supposedly progressive US was to be perceived as the defender of freedom and democracy. ${ }^{4}$ While the Soviet Union, according to this view, established puppet states in Eastern Europe and was intent on undermining liberal democracy, the US implemented a policy of containment to oppose Soviet expansion. According to liberal or orthodox arguments, the US had aspired to return to a position of isolationism after the Second World War, but in the face of the Soviet threat accepted the role of Western leader in a global struggle against communist dictatorship. For traditionalists, the Marshall Plan and the formation of NATO, in which the US consolidated its new role, sprang from altruistic and defence-related motives. Bodies such as the UN are viewed as emphasising America's will to international cooperation.

Revisionist interpretations, on the other hand, see the US as a capitalist aggressor provoking a weakened Soviet Union which longed for security after the experience of war. The Soviet Union, according to this view, found itself in a position of defence against an expansionist US, which had long since begun to restrict Soviet influence (Lundestad 2014, 11). The Marshall Plan is considered part of an American expansionist agenda, primarily motivated by economic interests. ${ }^{5}$ Multilateral institutions are 
viewed as means to increase American power (Kolko and Kolko 1972). Western rhetoric, including the metaphor of the Iron Curtain, is seen as having further contributed to the conflict (Williams and Appleman 1972, 159-260; 269-270; Medhurst, Ivie and Wander 1997).

Post-revisionist views on the Cold War and its origins exist in diverse forms. Adopting revisionist arguments to varying degrees, post-revisionists focus on the role of (mis)perceptions and the diversity of motives. Pointing out how both superpowers contributed to the outbreak of the Cold War, they argue either that the conflict was inevitable and neither side can be held responsible, or that both sides are equally to blame (Lundestad 2014, 11-12).

\section{The American Vision (Appleby et al. 2007) and The Americans (Danzer et al. 2012)}

Both these textbooks devote around 22 percent of their content to the Cold War, ${ }^{6}$ covering political as well as social and/or cultural aspects. While both have sections entitled 'Origins of the Cold War', however, they differ in their definitions of these 'origins': In The Americans, this section of eight pages includes, among other things, the formation of NATO and the Marshall Plan. In The American Vision, these two issues are discussed in the subsequent section 'The Early Cold War Years'. The section on the 'Origins of the Cold War' is therefore only five pages long. As my analysis will show, the organisation of topics contributes to their interpretation.

\section{The Origins of the Cold War in The American Vision (Appleby et al. 2007)}

The American Vision makes revisionist and post-revisionist perspectives on the beginnings of the Cold War compatible with the overall master narrative. It does so by rendering the latter the basis for selectivity: While 
lending credibility to the idea that the Soviet Union was a victim motivated by true convictions and fears, the chapter 'Origins of the Cold War' does not include the converse argument that the US was a capitalist aggressor. Instead, it combines the more lenient reassessment of the Soviet Union with a positive (traditionalist) self-image. This strategy partly relies on the organisation of topics: The chapter focuses on the general beliefs and concerns held by each side and on differences between the two. Many specific events, such as the Marshall Plan and the formation of NATO, are not covered before the chapter 'The Early Cold War Years', which recreates a traditionalist interpretative framework.

\section{(Post-)Revisionist and Traditionalist Elements in the Chapter 'Origins of the Cold War'}

The chapter 'Origins of the Cold War' begins by describing how the 'clash of interests' between the US and the Soviet Union after the Second World War 'led to an era of confrontation and competition' that 'became known as the Cold War' (778). A purely traditionalist account would continue to construct this clash as one between communist dictatorship and capitalist democracy. This textbook, however, contrasts 'Soviet security concerns' with 'American economic concerns' (779). These headings may raise expectations of a post-revisionist account in which both superpowers pursued their self-interested preoccupations. The heading 'Soviet Security Concerns' is prone to a revisionist reading implying that the Soviet Union was weak. As we shall see, however, this expectation is only partly fulfilled.

The section under this heading represents the Soviet side of the conflict. It lends legitimacy to the Soviets' suspicion of capitalist nations while simultaneously exonerating these nations of blame:

$(1)^{7}$ As the war ended, Soviet leaders became concerned about security. (2) The Soviets wanted to keep Germany weak and make sure that the countries between Germany and the Soviet Union were under Soviet control. (3) Although security concerns influenced their thinking, Soviet leaders were also Communists. (4) They believed that communism was a superior economic system that would eventually replace capitalism and that the Soviet Union should encourage communism in other nations. (5) Soviet 
leaders also accepted Lenin's theory that capitalist countries eventually would try to destroy communism. (6) This made Soviet leaders suspicious of capitalist nations. (Appleby et al. 2007, 779)

Despite traditionalist elements, this passage contains several revisionist aspects: it explains 'Soviet control' over other countries in terms of the Soviet need for security (1-2), it represents the Soviet ambition of spreading the communist system as based on true conviction (4), and it asserts that the Soviet Union felt threatened by capitalism (5). In addition, the text refrains from explicitly judging communism.

At the same time, the text avoids placing blame on the US. The issue of 'Soviet security concerns' leads to the implicit question as to why the Soviets mistrusted capitalist nations (6). The highly ambivalent (Baier, Christophe and Zehr 2014) sentence 3 is particularly relevant here: The conjunction 'although' can be read as creating a contradiction between being concerned about security and being communist, as if communists should not, or do not usually have, security concerns. The sentence, however, can also be interpreted as claiming that security concerns were not the sole factors behind Soviet thinking, but that communism was also of influence. The precise relationship between the two driving forces remains unclear: Did security concerns and communism go hand in hand or contradict each other? Which was more important? By keeping this relationship ambiguous, the text manages to represent the perceived capitalist threat as a merely theoretical construct: Because Soviet leaders 'accepted Lenin's theory that capitalist countries eventually would try to destroy communism' (5), they were 'made ... suspicious of capitalist nations' (6). While making an effort to rationalise Soviet thinking, the text thus precludes the idea that Soviet security concerns had anything to do with specific action on the part of the US.

The contrasting representation of the American perspective under the heading 'American economic concerns' complements the picture:

(7) While Soviet leaders focused on securing their borders, American leaders focused on economic problems. (8) Many American officials believed that the Depression had caused World War II. (9) Without it, Hitler would never have come to power, and Japan would not have wanted 
to expand its empire. (10) American advisers also thought the Depression had been overly severe because countries cut back on trade. (11) They believed that when nations seal themselves off economically, it forces them to go to war to get the resources they need. (12) By 1945, President Roosevelt and his advisers were convinced that economic growth was the key to world peace. (13) They wanted to promote economic growth by increasing world trade. (14) Similar reasoning convinced American leaders to promote democracy and free enterprise. (15) They believed that democratic government with protection for people's rights made countries more stable and peaceful. (16) They also thought that the free enterprise system [...] was the best route to prosperity. (Appleby et al. 2007, 779)

On the surface, the text places the US on an equal footing with the Soviet Union: In a manner similar to that of the previous passage, it explains what Americans 'believed' $(8,11,15)$, 'thought' $(10,16)$ and were 'convinced' of (12) without explicitly positioning itself towards their principles and conclusions. Both passages present the respective way of thinking as based on economic rather than moral considerations: The Soviets thought communism a 'superior economic system' that should therefore be 'encourage[d]' 'in other nations' (5). The Americans, who 'believed that the Depression had caused World War II' (8), promoted democracy not so much as a value in its own right but as part of an economically based solution to conflict. The passages consistently speak of 'leaders' (3, $5,6,7,14)$, 'officials' $(8)$ or 'advisers' $(10,12)$ rather than of the people. Taken together, the paragraphs thus suggest that each superpower had reason to believe itself in the right and, consequently, to act as it did. In this sense, the text makes a strong post-revisionist statement.

It also, however, upholds the idea of American moral superiority. While raising the expectation of a revisionist or post-revisionist interpretation, the heading 'American economic concerns' turns out to be ambiguous: These 'concerns' do not refer to matters of self-interest, but rather to more general problems of the time which the US was supposedly trying to solve via an economic approach. The text thus plays with a revisionist catchword explicated in an unexpected way. Given this reinterpretation of the concept 'economic concerns', sentence 7 in particular portrays the Americans in a more altruistic light than the Soviets. 
The chapter continues to present the relationship between the two sides in the same fashion: While upholding the idea of different perspectives, each with its own legitimacy, the text depicts the US as more altruistic. Regarding the Potsdam Conference in 1945, for example, it asserts:

(17) Truman was now convinced that German industry was critical. (18) Unless Germany's economy was allowed to revive, the rest of Europe would never recover, and the German people might turn to Communism out of desperation. (19) Stalin and his advisers were equally convinced that they needed reparations from Germany. (20) The war had devastated their economy [...]. (21) Truman [...] suggested that the Soviets take reparations from their zone [...]. (22) Stalin opposed this idea since the Soviet zone was mostly agricultural. (23) It could not have provided all of the reparations [...]. (24) At Potsdam, Truman learned that the atomic bomb had been successfully tested, and he told Stalin about the test. (25) Stalin suspected Truman was trying to bully him into a deal and that the Americans were trying to limit reparations to keep the Soviets weak. (Appleby et al. 2007, 781)

Contrasting the opposing camps, this passage, on the one hand, depicts them as 'equally convinced' (19) of their concerns and positions, and provides reasons for both sides' lines of argumentation (17-23). In the case of the Soviet Union, it does so by drawing again on the revisionist idea that the country was a victim of the Second World War $(20,25)$. Without judging either side, the passage also portrays the communication regarding the testing of the atomic bomb as an honest misunderstanding (24-25), which is characteristic of a post-revisionist perspective. While the US appears to be primarily concerned with Europe's wellbeing, however, Soviet interests seem egocentric, as they only relate to the payment of reparations to the Soviet Union.

As demonstrated, the text as a whole employs post-revisionist perspectives both in the equal apportioning of blame to each side and in the non-apportioning of guilt. It also adopts revisionist elements in pointing out the Soviet Union's precarious position after the war. The acceptance of alternative views, however, seems to end where such views might question the idea of US altruism, as the direct comparison of 
American with Soviet reasoning indicates. The notion that the Soviet Union was not purely egocentric consequently only occurs in parts of the chapter where the Soviet Union is not directly contrasted with the US. The reader is informed, for example, that Soviet troops 'liberated Poland from German control' in 1944 (779), and that the so-called satellite nations were 'not under direct Soviet control' (782).

The early Cold War largely appears as an inevitable conflict. 'Over the next few years', we are told, 'arguments about reparations and economic policy in Germany increased tensions between the United States and the Soviet Union. These arguments became one of the major causes of the Cold War' (780). Similarly, 'the Potsdam conference marked yet another increase in tensions between the Soviets and the Americans, further paving the way for the Cold War' (782). These post-revisionist assessments are possible because they do not generally contradict the notion of American moral superiority.

In one instance, the post-revisionist perspective creates a degree of tension with the concept of American altruism. Next to a half-page photograph of a little boy holding a pair of shoes donated through the American Red Cross we find the assertion that ' $t]$ he fate of [German] refugees became enmeshed in the growing power struggle between the United States and the Soviet Union' (780). This assessment mirrors a recent shift in historiographical debate about German victimhood (Kleßmann 2010). It implies that the superpowers cared more about their dispute as such than about countries and people, rendering them both egocentric. The information that the shoes were given to the boy by the American Red Cross, on the other hand, counters the suggestion of blame assigned to the US by representing the Americans as caring.

Partly characterised by the absence of critique on US actions, the chapter 'Origins of the Cold War' upholds central aspects of the American master narrative. I argue that the inclusion of non-traditionalist elements is also possible because subjects of debate whose alternative interpretation would necessarily cast the US in a less favourable light, such as the Marshall Plan, find themselves removed to the chapter 'The Early Cold War Years'. 


\section{Traditionalist Framework in the Chapter 'The Early Cold War Years'}

This chapter follows that on the 'Origins of the Cold War' and realigns the narrative to a traditionalist framework. It introduces ideas that clearly oppose the previous mode of representation and resumes and develops traditionalist elements from the previous chapter, thus creating a degree of narrative continuity.

A text box at the beginning summarises the main idea as follows: 'As the Cold War began, the United States struggled to oppose Communist aggression in Europe and Asia through political, economic, and military measures' (783). This traditionalist introduction places the US in a position of defence while representing communism, and thus the Soviet Union, as the aggressor. While the previous chapter portrayed the developing conflict between the superpowers as inevitable, the Soviet Union now clearly becomes the scapegoat. Whereas the newly introduced notion of communist aggression is in conflict with the previously established concept of Soviet victimhood, the similarly new idea of the defensive US does not immediately contradict earlier depictions, as the overall image remains positive.

The chapter continues with paragraphs about major Cold War events, such as the Marshall Plan, the formation of NATO, and the Suez crisis. I will analyse the discussion of the Marshall Plan to illustrate the chapter's mode of representation.

The passage begins with a description of the poverty, starvation and political chaos prevailing in Western Europe after the end of the war. It then explains how Secretary of State George C. Marshall proposed the Marshall Plan, 'which would give European nations American aid to rebuild their economies' and was 'essential to containment' (785). This is followed by Marshall's famous assertion that the Plan was 'not directed against any country or doctrine' (ibid.). The core text continues:

(26) The Soviet Union and its satellite nations rejected the offer. (27) Instead, the Soviets developed their own economic program. (28) This action further separated Europe into competing regions. (29) The Marshall Plan pumped billions of dollars $[s i c]$ worth of supplies, machinery and 
food into Western Europe. (30) Western Europe's recovery weakened the appeal of communism and opened new markets for trade (Appleby et al. 2007, 785).

Portraying the Americans as the saviours of Western Europe, this passage ties in with the positive image of the US. The revisionist view, according to which the Marshall Plan was primarily designed to serve US economic interests, is hinted at in the last part of sentence 30 but simultaneously at least partially refuted: The position of the statement at the very end of the paragraph allows a reading in which the opening of new markets is a consequence or side effect rather than a motive. Even if we were to interpret it as a motive, the previously established idea that the US believed in global trade as a route to peace does not make its actions appear primarily selfish.

The representation of the Soviet Union complements the traditionalist image. First, the text does not clarify why the Soviet Union 'and its satellite nations' rejected the ostensibly generous offer (26). This is clearly in contrast with the previous chapter's efforts to explain why accepting America's offer to make reparations did not make sense from a Soviet perspective. Here it is claimed that the Soviets' actions in developing their own economic program 'further separated Europe into competing camps' (27). In traditionalist fashion, the Soviet Union is thus blamed for the growing conflict.

A facilitating factor of this purely traditionalist representation of the Marshall Plan is its inclusion in the textbook chapter on the 'Early Cold War Years' rather than in the 'Origins of the Cold War'. In light of the chapter's scene-setting, which puts forward the claim that 'the United States struggled to oppose Communist aggression in Europe and Asia' (783), the Marshall Plan is effectively construed as a necessary measure for saving the world. Had it been treated in the chapter on the 'Origins of the Cold War', there may have been an implication that the Marshall Plan lay at, or was among, the roots of the conflict.

While The American Vision's chapter on the 'Origins of the Cold War' includes revisionist and post-revisionist perspectives, particularly on the Soviet Union, the chapter 'The Early Cold War Years' leads the overall account back into a traditionalist narrative. Considered as a whole, the 
two chapters thus draw an ambivalent picture of the Soviet Union while representing the US in a relatively coherent, positive way. A depiction of German refugees as the ultimate victims of the Cold War indicates how international historiographical discourse has also found its way into US textbook narratives. The purely traditionalist representation of crucial events such as the Marshall Plan is partly enabled by the chapters' thematic structure and organisation.

\section{The Origins of the Cold War in Holt McDougal/ Houghton Mifflin Harcourt's The Americans}

Unlike The American Vision, the textbook The Americans covers all crucial events of the early Cold War in the chapter 'The Origins of the Cold War'. My analysis will demonstrate how the chapter simultaneously includes and marginalises revisionist interpretations by employing the strategy of physical separation: The main text consists of a post-revisionist and a traditionalist part, while revisionist interpretations are relegated to side boxes and graphs. There is one instance, however, in which fissures appear in the core narrative and revisionist elements enter; ambiguity ensues.

\section{The Post-Revisionist and Traditionalist Framework}

The first half of the chapter's core text is characterised by a post-revisionist framework. This begins on the first page; a personal story revolves around the encounter of US and Soviet soldiers at the Elbe River in Germany at the end of the Second World War. The section ends with the following assessment:

(31) The Soviet and U.S. soldiers believed that their encounter would serve as a symbol of peace. (32) Unfortunately, such hopes were soon dashed. (33) After World War II, the United States and the Soviet Union emerged as rival superpowers, each strong enough to greatly influence world events (Danzer et al. 2012, 808). 
This passage can be read as post-revisionist in a multiple sense. First, it puts the Soviet Union and the US grammatically and semantically in equal, or parallel, positions. Sentence 32 evaluates the end of hope for peace as negative but refrains from assigning guilt. The claim that the US and the Soviet Union 'emerged' as rival superpowers contributes to the idea of a dynamic of inevitability (33). The remainder of sentence 33 contrastingly implies that the Soviet Union and the US are both to blame for the unfortunate outbreak of the Cold War, as 'each' superpower was 'strong enough to [...] influence world events'.

On the next page, the text reinforces the idea that both sides were equally to blame for the Cold War and that their conflict formed a counterpart to the concept of 'peace'. After contrasting 'Soviet communism' with 'the capitalist American system' (809) and describing the mutual Soviet-American suspicion, it elaborates on the relationship between the superpowers, the concept of peace, and the UN:

(34) $[\mathrm{H}]$ opes for world peace were high at the end of the war. (35) The most visible symbol of these hopes was the United Nations (UN). (36) On April 25, 1945, the representatives of 50 nations met in San Francisco to establish this new peacekeeping body. [...] (37) Ironically, even though the UN was intended to promote peace, it soon became an arena in which the two superpowers competed. (38) Both the United States and the Soviet Union used the UN as a forum to spread their influence over others (Danzer et al. 2012, 809).

The first part of this passage addresses the concepts of 'hope' and 'peace' in connection with the institution of the UN as such (34-36). Proceeding from this basis, the text constructs the United States and the Soviet Union as the combined destroyers of general hopes for peace, who misused the UN as a competitive 'arena' and as a 'forum to spread their influence over others' (37-38). Depicting both superpowers as egocentric and greedy for power, the text places equal blame on each.

In contrast, the second half of the chapter represents a largely traditionalist account of the origins of the Cold War. This is apparent in the individual portrayals of the superpowers and depictions that set them in relation to each other. One primary example is the representation 
of America's establishment of its containment policy. The text, while indirectly blaming the Soviet Union for the implementation of this policy, minimises American responsibility:

(39) Stalin installed communist governments in Albania, Bulgaria, Czechoslovakia, Hungary, Romania, and Poland. (40) These countries became known as satellite nations, countries dominated by the Soviet Union. (41) In early 1946, Stalin gave a speech announcing that communism and capitalism were incompatible - and that another war was inevitable.

(42) Faced with the Soviet threat, American officials decided it was time, in Truman's words, to stop 'babying the Soviets.' (43) In February 1946, George F. Kennan, an American diplomat in Moscow, proposed a policy of containment. (44) By containment he meant taking measures to prevent any extension of communist rule in other countries. (45) This policy began to guide the Truman administration's foreign policy (Danzer et al. 2012, 811).

These two paragraphs portray the superpowers in traditionalist Western terms. First, the Soviet Union is depicted as 'dominat [ing]' other countries (39-40). Using the metaphor of 'satellite nations' (40), the first paragraph upholds the idea of Eastern European puppet states that were entirely subject to the Soviet Union. Linking the paragraphs, the phrase '[f]aced with the Soviet threat' (42) interprets Stalin's speech (41) as an immediate threat requiring a counter-reaction from the US. While the Soviet Union is assigned the role of aggressor, the US becomes the defender who 'prevent[ed] any extension of communist rule' (44). The image of a generally benign US receives further support from the text's citation of the decision by American officials "to stop "babying the Soviets" (42). While marked as a quotation, this statement is not questioned and is thus depicted as describing the situation accurately. It suggests that the US had been disproportionately soft and patient in the past but had finally reached the end of its tether; that the Soviet Union, through its provocative behaviour, had exhausted its generous chances and that the US now intended to meet the Soviets on equal terms. The text obscures US responsibility and initiative not only in relation to the initial establishment of the policy of 
containment, but also with reference to its further implementation: The final sentence, ' $\mathrm{t}$ ] his policy began to guide the Truman administration's foreign policy' (45), constructs the policy itself as the active subject by which the Truman administration is passively led. Putting American government policy, and by extension the government itself, in the position of an object, this depiction implies that the US could not have changed the course of events. The text thus holds the Soviet Union responsible for the US policy of containment in the sense that its behaviour rendered it necessary and inevitable.

The strategy of indirectly blaming the Soviet Union for the growing tensions is continued in the text's depiction of the Iron Curtain, which follows on from the passage above. The insertion of a primary source plays a major role here:

(46) Europe was now divided into two political regions, a mostly democratic Western Europe and a communist Eastern Europe. (47) In March 1946, Winston Churchill travelled to the United States and gave a speech that described the situation in Europe.

(48) A shadow has fallen upon the scenes so lately lighted by the Allied victory. ... From Stettin in the Baltic to Trieste in the Adriatic, an iron curtain has descended across the Continent. Behind it lie all the capitals of the ancient states of Central and Eastern Europe. ... all these famous cities and the populations around them lie in ... the Soviet sphere, and all are subject in one form or another, not only to Soviet influence but to a very high and ... increasing measure of control from Moscow.

(49) The phrase 'iron curtain' came to stand for the division of Europe. (50) When Stalin heard about the speech, he declared in no uncertain terms that Churchill's words were a 'call to war' (Danzer et al. 2012, 811).

The text begins by constructing the difference between East and West traditionally in terms of 'democracy' versus 'communism' as mutually exclusive concepts (46). The traditionalist view is upheld in the citation of Churchill's speech, which portrays the Soviet Union as a highly influential and controlling power (48). The contextualisation of the quotation further supports the construction of Soviet responsibility and 
the concealing of Western acts of aggression. First, the speech by Churchill is said to have 'described the situation in Europe' rather than having contributed to it (47). This idea is reinforced by the affirmation that ' $[\mathrm{t}] \mathrm{he}$ phrase "iron curtain" came to stand for the division of Europe' (49), which implies endorsement of the phrase as a fitting term to describe the situation. Unlike Stalin's speech in the section analysed above, which was represented as a 'threat' that provoked an American counter-reaction (41), Churchill's speech does not appear to have intensified the conflict between East and West, but to have merely put it into words. The text thus deviates from the (post-)revisionist notion that the speech, and Western rhetoric in general, fuelled the conflict. Moreover, the quotation marks around the term 'a call to war' in sentence 50 indicate that Stalin's interpretation of the speech as an act of aggression was subjective and inaccurate. At the same time, the phrase 'in no uncertain terms' reinforces the image of a hostile Soviet Union unwilling to compromise. By implying that Stalin, perhaps deliberately, misinterpreted Churchill's words, the passage thus ultimately blames the Soviet Union for the outbreak of the Cold War.

The core text continues its traditionalist storyline in many ways. For instance, it describes the Truman Doctrine as 'essential to keeping Soviet influence from spreading' (812). In the section about the Berlin Airlift, a photograph of children looking up at an approaching aircraft covers half a page (813), reinforcing the concept of American heroism. In the following section, I aim to demonstrate how the textbook systematically relegates revisionist elements to the background. I will also analyse an instance in which they appear to become prominent.

\section{The Inclusion and Exclusion of Revisionist Views}

I argue that the minimisation of revisionist views in the representation of the origins of the Cold War in The Americans takes place by three means: Either these views are rendered invisible, or they are kept separate from the core narration, or they are included in the core narration but weakened by means of ambiguity. 


\section{Rendering Revisionist Elements Invisible: The Representation of NATO}

The representation of the formation of NATO is an example of the first form of minimisation: A revisionist primary source is adopted, but does not become visible as such, as it is embedded in a traditionalist story. The beginning of the relevant paragraph reads as follows:

(51) The Berlin blockade increased Western European fear of Soviet aggression. (52) As a result, ten Western European nations [...] joined with the United States and Canada on April 4, 1949, to form a defensive military alliance called the North Atlantic Treaty Organization (NATO). (53) For the first time in its history, the United States had entered into a military alliance with other nations during peacetime. (54) The Cold War had ended any hope of a return to U.S. isolationism (Danzer et al. 2012, 814).

Next to the text, a cartoon by Edwin Marcus depicts the US, France, Britain, Canada, Norway, Belgium, the Netherlands and Luxembourg as hats on a stand. The hats of the first three countries are large and at the bottom (the US being the lowest and largest), whereas the latter five are smaller and on top. The caption reads:

(55) This cartoon depicts the nations that signed the North Atlantic Pact, which created NATO in 1949. The nations, shown as hats, are arranged in a pyramid to show the bigger countries on the bottom supporting the smaller, weaker nations on top (Danzer et al. 2012, 814).

The traditionalist narrative in the core text is constructed on two levels. Depicting the creation of NATO as a 'result' of 'Soviet aggression' and thus as an act of 'defense' (51-52), the text places the Soviet Union in the role of the aggressor and the West in the role of the defender. Sentence 54 further suggests that American involvement in world affairs was altruistic in general, as the US had actually hoped to 'return' to 'isolationism'; this reading mirrors the so-called liberal or orthodox interpretation. Complementing the positive image of the US, the cartoon and its description reinforce the concept of an altruistic West under US leadership, which was 'supporting [...] smaller, weaker nations' (55). 
Ironically, this editorial cartoon from 1949 was originally intended to criticise power relations within NATO; that is, its origins are rather revisionist. Its original caption - 'Another pyramid party' - is to be found only in the index of the textbook. Consulting the website of the Library of Congress, I found that the caption 'refers to the parties held to promote pyramid investment clubs - gambling investment schemes then popular in New York', and that the cartoon may 'suggest that, as in the pyramid clubs, some members of NATO will profit far more than others' (Library of Congress 2018). The textbook thus re-interprets a primary source critical of the US to render it compatible with a traditionalist perspective on the Cold War.

\section{Keeping the Revisionist Interpretation Separate from the Core Text: The Representation of the Marshall Plan}

In the case of the Marshall Plan, revisionist views are not rendered invisible altogether, but are kept separate from the core text. The main text introduces the topic via a detailed description of the horrific socioeconomic situation in Western Europe after the World War, when 'most factories had been bombed or looted', while '[m]illions of people were living in refugee camps', and a bitterly cold winter had caused starvation and water and fuel shortages (Danzer et al. 2012, 812). This description, which resembles that in The American Vision, provides the basis for a traditionalist account of American actions and their consequences:

(56) In June 1947, Secretary of State George Marshall proposed that the United States provide aid to all European nations that needed it, saying that this move was directed 'not against any country or doctrine but against hunger, poverty, desperation, and chaos.' The Marshall Plan revived European hopes. Over the next four years, 16 countries received some 13 billion dollars in aid. By 1952, Western Europe was flourishing (Danzer et al. 2012, 812).

The passage is accompanied by a photograph showing how American goods are loaded, presumably onto a ship, as well as a graph showing the amount of US aid, quantified in millions of dollars, that went to the 
individual countries. These elements go to create a clear depiction of the US as an altruistic saviour. While the core text provides a traditionalist account, the revisionist view is relegated to literally sidelined - or marginalised - information, in a smaller font, headed 'background'. In contrast to the main text, this section emphasises the Marshall Plan's economic benefits to the US:

(57) The Marshall Plan also benefited the United States. (58) To supply Europe with goods, American farms and factories raised production levels. (59) As a result, the American economy continued its wartime boom.

Physically relegating this information to the 'background' allows the text to subtly include a revisionist element in the core narrative. The label 'background' implies that the information is of secondary relevance.

\section{Weakening Revisionist Elements in the Core Narrative: The Representation of the Soviet Union}

I will now look at the only instance, according to my reading, in which the main text incorporates revisionist views on the origins of the Cold War. It occurs in a short subsection headed 'Tension Mounts', which is located between the post-revisionist and the traditionalist parts of the core text. The technique of incorporating revisionist elements creates ambiguity, as these elements are interwoven with traditionalist ideas. This happens with respect to both the US and the Soviet Union:

(60) Stalin's refusal to allow free elections in Poland convinced Truman that U.S. and Soviet aims were deeply at odds. (61) Truman's goal in demanding free elections was to spread democracy to nations that had been under Nazi rule. [...] (62) Truman also felt that the United States had a large economic stake in spreading democracy and free trade across the globe. (63) U.S. industry boomed during the war, making the United States the economic leader of the world. (64) To continue growing, American businesses wanted access to raw materials in Eastern Europe, and they wanted to be able to sell goods to Eastern European countries. 
(65) Soviets Tighten Their Grip on Eastern Europe. (66) The Soviet Union had also emerged from the war as a nation of enormous economic and military strength. (67) However, unlike the United States, the Soviet Union had suffered heavy devastation on its own soil. (68) Soviet deaths from the war have been estimated at 20 million, half of whom were civilians. (69) As a result, the Soviets felt justified in their claim to Eastern Europe. (70) By dominating this region, the Soviets felt they could stop future invasions from the west (Danzer et al. 2012, 810).

The first passage commences with a traditionalist representation of a freedom-loving US and an undemocratic Soviet Union (60-61). In sentences 62 to 64, the positive image of the US is countered by arguments that, in revisionist fashion, emphasise America's economic self-interests. The relationship between the concept of 'democracy' and economic benefits is highly ambiguous here. While they stem from opposing perspectives on the US, sentence 62 constructs them as essentially a single entity, or two sides of a coin. The text thus indicates that the spread of democracy was related to US economic growth, but it does not explain the nature of this relationship. One possible reading is that democracy equals capitalism, which would again reinforce traditionalist arguments. While employing revisionist elements, the passage thus neglects to fully develop them.

In the second passage, a similar phenomenon can be observed with regard to the Soviet Union. On the one hand, the Soviet Union is depicted from a revisionist perspective as a victim of the Second World War, having 'suffered heavy devastation' and lost millions of civilians (67). Emphasising that this condition was 'unlike [that in] the United States' (67), the text creates a contrast to Soviet 'economic and military strength' (66) and implies that the Soviet Union was no rival for the US on an equal footing. The text also gives reasons for the Soviets' 'claim to Eastern Europe' (69) and, by mentioning potential 'future invasions from the west' (70), evokes the revisionist image of an aggressive West and a defensive Soviet Union. At the same time, however, the text refrains from taking a clear position: The verb 'felt' $(69,70)$ emphasises the subjectivity of the Soviet view, implying that the latter might have wrongly believed that they could prevent invasions by claiming power over Eastern Europe. Whether 
this error came about because they had chosen the wrong measures or because such a threat had not existed in the first place, remains unclear. At the end of the paragraph, the Soviet Union is back in its role as a 'dominating' power (70). This also corresponds with the paragraph's heading, 'Soviets Tighten Their Grip on Eastern Europe' (65), which is reminiscent of traditionalist catchphrases. Ambiguity thus helps here to conceal the contrast that emerges through the employment of revisionist elements intertwined with traditionalist ones.

The conflict, however, remains visible, and re-emerges in the exercises at the bottom of the page, which ask students to identify which aims 'involved economic growth of the United States', and which 'Soviet aims involved self-protection' (810). This task is clearly in conflict with the traditionalist part of the book that follows it.

We have thus seen that the main text of The Americans' chapter on 'The Origins of the Cold War' is divided into a post-revisionist part, covering general ideological differences and the formation of the UN, and a traditionalist part covering issues such as the Marshall Plan, the Truman Doctrine, the Berlin Airlift, and the formation of NATO. Revisionist elements can be found both in relation to the US and the Soviet Union. While some are rendered invisible or occur as separate background information, others enter the core narrative but are kept ambivalent.

\section{Conclusion}

My analysis has shown that two major US history textbooks apply to the Cold War some of the strategies of incorporation and separation that have been deployed for other controversial issues in American history textbooks in the past. Both textbooks examined here contain postrevisionist and traditionalist perspectives.

Their simultaneous use of various interpretative patterns mirrors academic debate, specifically a lack of consensus over Cold War history: We find, for example, traditionalist perspectives and elements of revisionist interpretations of the Marshall Plan, traditionalist, revisionist and postrevisionist views on American and Soviet goals, a post-revisionist account of the UN, a liberal-traditionalist view on the formation of 
NATO accompanied by a revisionist cartoon, and revisionist headings for non-revisionist paragraphs, alongside frequent combinations of different forms of post-revisionism.

The textbooks do not, however, grant equal status to the various patterns of interpretation. At the core of this seems to be a reluctance to openly criticise the US. While both traditionalist and post-revisionist views are treated as valid frameworks for interpretation, there is a tendency to employ post-revisionism in a way that conserves a positive national self-image. Meanwhile, revisionist perspectives are mitigated, pushed into the background, and/or omitted in direct comparisons between the US and the Soviet Union. While a purely negative image of the Soviet Union thus seems to be in decline, the positive image of the US still finds strong narrative support.

These findings argue against the assumption that questions of guilt and responsibility are no longer an important issue in current historiographical discourse, and that historiography has left behind the argumentative patterns of the Cold War era. ${ }^{8}$ The concept of the Cold War as a 'good war' that resulted in American triumph, a notion John Wiener (2012) describes as a failed project of conservative US memory politics, seems to have a stronger basis than generally assumed (cf. Schrecker 2004). While low visitor numbers at Cold War memorials and museums (Wiener 2012) might suggest otherwise, history textbook narratives - and what they construe as common sense - make evident to this day the traces of 'American Cold War Culture's in historical discourse.

Individual instances of revisionist elements entering the core narrative in the textbook The Americans suggest that we are nonetheless dealing with a fragile, ever-shifting construct. Whereas some critics from the world of education bemoan increasingly incoherent storylines in US history textbooks (see Ravitch 2004), we might regard the crumbling of the core master narrative as a sign of alternative perspectives becoming more accepted and thus of what Apple $(1990,26)$ might call a victor[y] in the politics of official knowledge'. The instance of a discourse of German victimhood in The American Vision further proves that the internationalisation of academia has an impact on the way national history is told. As the role of the US in the twenty-first century is changing and US history is increasingly studied from inter- and transnational 
perspectives, the long-term response of history textbooks to the associated challenges and necessary amendments to the traditional master narrative remains to be observed.

\section{Notes}

1. The quotation cites a member of the conservative faction on the Texas State Board of Education.

2. The Advanced Placement (AP) Program was created by the American College Board and offers college-level courses to high-school students.

3. In the argument referenced here, Apple draws on Tyson-Bernstein (1988, 18-19).

4. Here and in the following I refer to the useful summaries provided by Lundestad 2014, 8-34 and Byrd 2009, 88-90.

5. This line of argumentation can be found, for example, in Cox and Kennedy-Pipe 2005, 97-134.

6. In Appleby et al. 2007, this amounts to 234 of 1039 pages (excluding the appendix); in Danzer et al. 2012, the figure is 246 of 1123 pages.

7. The numbers in parentheses are added by the author for purposes of reader orientation.

8. This argument is brought forward, among others, by Jarausch, Ostermann and Etges $(2017,1-18 ; 4)$.

9. This term was coined by Stephen Whitfield (1991).

\section{Bibliography}

\section{List of Textbooks Cited}

Appleby, Joyce, Alan Brinkley and James M. McPherson. 2007. The American Journey. Glencoe/McGraw Hill.

Appleby, Joyce, Alan Brinkley, Albert S. Broussard, James M. McPherson and Donald A. Ritchie. 2007. The American Vision. Glencoe McGraw Hill.

Danzer, Gerald A., J. Jorge Klor de Alva, Larry S. Krieger, Louis E. Wilson and Nancy Woloch. 2012. The Americans. Holt McDougal/Houghton Mifflin Harcourt. 
Deverell, William Francis and Deborah Gray White, eds. 2012. United States History. Orlando, Fla.: Holt McDougal/Houghton Mifflin Harcourt.

Divine, Robert A; T. H. Breen, George M. Fredrickson, R. Hal Williams, Ariela J. Gross, H. W. Brands. 2007. America: Past and Present, $8^{\text {th }}$ edition. Pearson/ Longman.

Nash, Gary B. and Julie Roy Jeffrey, eds. 2009. The American People: Creating a Nation and a Society. VangoBooks/Pearson Education.

\section{Other Primary Sources}

Library of Congress. 2018. Image of Cartoon by Edwin Marcus (1949), Another Pyramid Party. Retrieved from the Library of Congress website: https://www. loc.gov/pictures/item/2016683485/ (accessed 15 November 2018).

McKinley, James C. 2010. 'Texas Conservatives Win Curriculum Change. Published in The New York Times, 12 March 2010. http://www.nytimes. com/2010/03/13/education/13texas.html (accessed 4 October 2015).

'Texas Ready for Textbook Showdown'. NBC News, 19 May 2010. http://www. nbcnews.com/id/37220562/ns/us_news-life/t/texas-ready-textbookshowdown/\#.VdR4ZUaQa1Q (accessed 4 October 2015).

\section{Further References}

American Textbook Council. 2016. 'Widely Adopted History Textbooks'. http://historytextbooks.net/adopted.htm (accessed 28 April 2019).

Apple, Michael. 1990. 'The Text and Cultural Politics'. The Journal of Education and Thought (JET) 24 (3a). Special Edition: Embattled Books: The State of the Text: 17-33.

Baier, Katharina, Barbara Christophe and Kathrin Zehr. 2014. 'Schulbücher als Seismographen für Diskursive Brüche: Ein neuer Ansatz in der Kulturwissenschaftlichen Schulbuchforschung dargestellt am Beispiel der Analyse von Schulbucherzählungen über den Kalten Krieg.' In: Eckert. Working Papers 4. http://repository.gei.de/bitstream/handle/11428/139/861 817958_2016_A.pdf (accessed 18 December 2016)

Barton, Keith C. and Linda S. Levstik. 2009. Teaching History for the Common Good. New York: Routledge.

Byrd, Peter. 2009. 'The Cold War'. In The Concise Oxford Dictionary of Politics, edited by Iain McLean and Alistair McMillan. 3rd edition. Oxford: Oxford University Press. 
Cox, Michael and Caroline Kennedy-Pipe. 2005. 'The Tragedy of American Diplomacy? Rethinking the Marshall Plan'. Journal of Cold War Studies 7, no. 1 (Winter): 97-134.

Foner, Eric. 1999. The Story of American Freedom. New York: Norton.

Höhne, Thomas. 2002. Schulbuchwissen: Umrisse einer Wissens- und Medientheorie. Frankfurt a. M.: Johann Wolfgang Goethe-Universität.

Issitt, John. 2004. 'Reflections on the Study of Textbooks'. History of Education 33, no. 6 (November): 683-696.

Jarausch, Konrad H., Christian F. Ostermann and Andreas Etges, eds. 2017. The Cold War: Historiography, Memory, Representation. De Gruyter.

Kleßmann, Christoph. 2010. '1945: Welthistorische Zäsur und "Stunde Null”'. Version 1:0. Docupedia-Zeitgeschichte, 15 October 2010. http://docupedia. de/zg/1945 (accessed 20 October 2016).

Klerides, Eleftherios. 2010. 'Imagining the Textbook: Textbooks as Discourse and Genre'. Journal of Educational Media, Memory and Society 2, no. 1: 31-54.

Kolko, Gabriel and Joyce Kolko. 1972. The Limits of Power: The World and United States Foreign Policy, 1945-1954. New York: Harper \& Row.

Lachmann, Richard and Lacy Mitchell. 2014. 'The Changing Face of War in Textbooks: Depictions of World War II and Vietnam, 1970-2009'. Sociology of Education 87, no. 3: 188-203.

Lowe, David and Tony Joel, eds. 2013. Remembering the Cold War: Global Contests and National Stories. (Remembering the Modern World.) Abingdon/ New York: Routledge.

Lundestad, Geir. 2014. 'The Cold War in Europe, 1945-1949: Some Old and New Theories about the Cold War'. In East, West, North, South: International Relations since 1945, edited by Geir Lundestad. London: SAGE.

Martin, J. R. and Ruth Wodak. 2003. Relreading the Past: Critical and Functional Perspectives on Time and Value. Amsterdam/Philadelphia: John Benjamins. Medhurst, Martin J., Robert L. Ivie, Philip Wander and Robert L. Scott, eds. 1997. Cold War Rhetoric: Strategy, Metaphor, and Ideology. East Lansing, Mich.: Michigan State University Press.

Moreau, Joseph. 2003. Schoolbook Nation: Conflicts over American History Textbooks from the Civil War to the Present. Michigan: Ann Arbor.

Paul, Heike. 2014. The Myths that Made America: An Introduction to American Studies. Bielefeld: transcript:.

Pease, Donald E. 2007. 'Exceptionalism'. In Keywords for American Studies, edited by Bruce Burgett and Glenn Hendler. New York: New York University Press. 
Ravitch, Diane. 2004. A Consumer's Guide to Highschool History Textbooks. Thomas B. Fordham Institute. http://files.eric.ed.gov/fulltext/ED485529. pdf, (accessed 30 March 2017).

Schissler, Hanna. 2009. 'Navigating a Globalizing World: Thoughts on Textbook Analysis, Teaching, and Learning'. Educational Media, Memory and Society 1, no. 1: 203-26.

Schrecker, Ellen. 2004. Cold War Triumphalism: The Misuse of History after the Fall of Communism. New York et al.: New Press.

Tyson-Bernstein, Harriet. 1988. A Conspiracy of Good Intentions: America's Textbook Fiasco. Washington: The Council for Basic Education.

Whitfield, Stephen. 1991. American Cold War Culture. Baltimore et al.: Johns Hopkins Univ. Press.

Wiener, John. 2012. How We Forgot the Cold War: A Historical Journey across America. Berkeley: University of California Press.

Williams, William Appleman. 1972 [1959]. The Tragedy of American Diplomacy. Second rev. ed. New York: Dell.

Open Access This chapter is licensed under the terms of the Creative Commons Attribution 4.0 International License (http://creativecommons.org/licenses/ by/4.0/), which permits use, sharing, adaptation, distribution and reproduction in any medium or format, as long as you give appropriate credit to the original author(s) and the source, provide a link to the Creative Commons licence and indicate if changes were made.

The images or other third party material in this chapter are included in the chapter's Creative Commons licence, unless indicated otherwise in a credit line to the material. If material is not included in the chapter's Creative Commons licence and your intended use is not permitted by statutory regulation or exceeds the permitted use, you will need to obtain permission directly from the copyright holder.

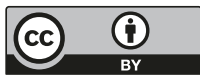

